\title{
Multiple myeloma in Jamaica: A study of 40 cases with special reference to the incidence a laboratory diagnosis
}

\author{
H. MCFARLANE \\ From the Department of Pathology, University of the West Indies, Mona, Kingston, Jamaica
}

SYNOPSIS For two years protein abnormality was studied in 40 cases of myelomatosis in Jamaî. Thirty-nine of these were in West Indian Negroes. The minimum incidence of myelomatosis in this group was estimated to be of the order of 50 cases per million per annum which is consideraWly higher than in Caucasians as reported by previous workers. A larger number showed myelog protein with $\beta$-globulin mobility and hypogammaglobulinaemia than with $\gamma$-globulin mobilgy. As in the Caucasians the disease is more common in men than in women and the age incidence-in both seems to be the same. Combined serum and urinary electrophoresis was diagnostic in eve्乛ुy case, and examination of the urine for Bence-Jones protein by electrophoresis yielded more conşstent findings than the classical heat test. It is suggested that combined serum and urine electronphoresis should be done in all cases of suspected myelomatosis.

Since electrophoresis was first used as an aid in the diagnosis of multiple myeloma in 1939 by Longsworth, Shedlowsky, and MacInnes, several reviews and several series on myelomatosis in Caucasians have been published. However, very little is known about the incidence of myeloma in the Negro race. Isolated cases have been published, and in a survey of myelomatosis in 34 Brooklyn hospitals, New York, MacMahon and Clark (1956) noted a higher incidence in Negroes than in Caucasians.

The occurrence of hypoproteinaemia and hypogammaglobulinaemia in myelomatosis is unusual and sometimes contributes to the difficulty experienced in the differential diagnosis of multiple myeloma, especially if either the bone marrow biopsy or the radiological appearance is inconclusive.

In the present series an attempt is made to study the incidence of multiple myeloma in the Negro race in Jamaica and to point out some important aspects concerning the laboratory diagnosis of myelomatosis, especially where the serum protein electrophoresis appears normal or shows only a hypogammaglobulinaemia.

\section{MATERIALS AND METHODS}

The material consisted of 40 cases in which myelomatosis

'Present address: Department of Chemical Pathology, University of Ibadan, Nigeria.

Received for publication 28 December 1965. was well documented. With the exception of one, Зall were Negroes. These were investigated in the course of our routine work in the Sub-department of Chemacal Pathology in the University of the West Indies betwgen 1962 and 1964. Twenty-five of these were men whose average age was 54 years (range 40-71 years). The 15 women had an average age of 50 years (range 40-65 years). The average for the whole group was 52 years, 吾d Table I shows the age incidence of myelomatosis in Jamaica.

TABLE I

AGE INCIDENCE OF MULTIPLE MYELOMA IN JAMAIC

\begin{tabular}{|c|c|c|}
\hline Age (yr.) & No. of Males & No. of Females \\
\hline $31-40$ & 5 & 3 \\
\hline $41-50$ & 9 & 6 \\
\hline $51-60$ & 6 & 5 \\
\hline $61-70$ & 3 & 1 \\
\hline $71-80$ & 2 & Nil \\
\hline Total & 25 & 15 \\
\hline
\end{tabular}

Electrophoresis by the method described by Vadtey (1962) was carried out on filter paper and also on cellutose acetate according to the method of McFarlane (19\%3). Both methods gave identical results. Samples of urme, each of $5 \mathrm{ml}$., were concentrated for approximately 90 minutes and electrophoresed according to the methof of McFarlane (1964). Urine electrophoresis for BenfeJones protein instead of the classical heat test qas adopted since it proved more reliable than the la fer. Total protein and globulin were estimated both by the 268 


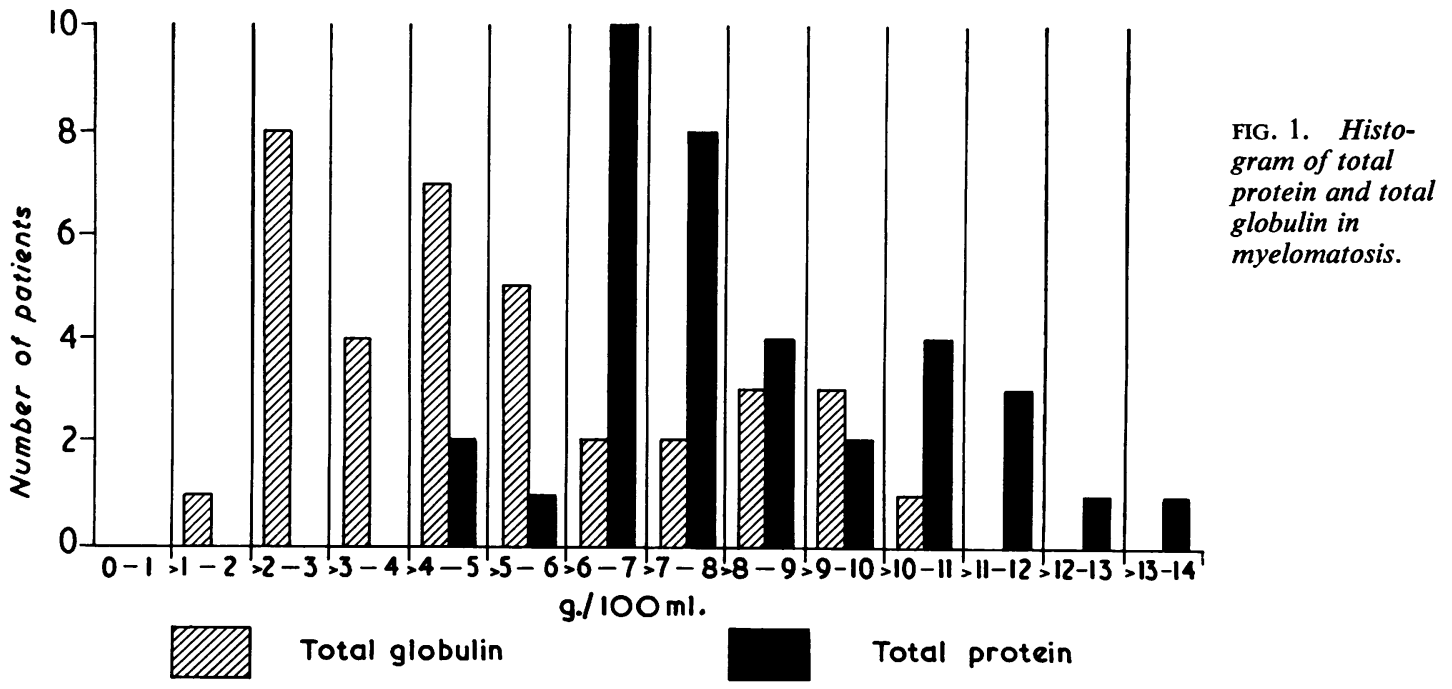

Biuret method (Gornall, Bardawill, and David, 1949) and by the Technicon AutoAnalyzer method.

\section{RESULTS}

TOTAL PROTEIN As shown in Fig. 1, of the 36 patients whose total protein was estimated, four (11\% of the total) had hypoproteinaemia with values between 4.0 and $6.0 \mathrm{~g} . / 100 \mathrm{ml} ; 17$ patients ( $47 \%$ of the total) had normal total protein concentration, that is, of values between 6.1 and 8.0 g. $/ 100 \mathrm{ml}$, whereas 15 , or $42 \%$, had hyperproteinaemia with values between 8.1 and $14.0 \mathrm{~g} . / 100 \mathrm{ml}$.

TOTAL GLOBULIN Figure 1 also shows the total globulin levels of the patients studied. Here it can be seen that nine cases, $25 \%$ of the patients, had relative hypoglobulinaemia, with values between 1.0 and $3.0 \mathrm{~g} . / 100 \mathrm{ml}$; four cases $(11 \%)$ had normal globulin values between 3.1 and $4.0 \mathrm{~g}$. $/ 100 \mathrm{ml}$., and 23 cases $(64 \%)$ had hyperglobulinaemia with values ranging from $4 \cdot 1$ to $11.0 \mathrm{~g} . / 100 \mathrm{ml}$.

SERUM ELECTROPHORESIS This was performed on all the sera. Sixteen cases showed a sharp beta globulin peak with hypogammaglobulinaemia, 14 a typical gamma globulin peak, in four cases there was a definite peak in the alpha region, and six cases gave a normal serum protein pattern on electrophoresis. When the urines of the latter were concentrated and electrophoresed a dominant band of globulin was invariably found in the $\beta-\gamma$ region, obviously the Bence-Jones protein.

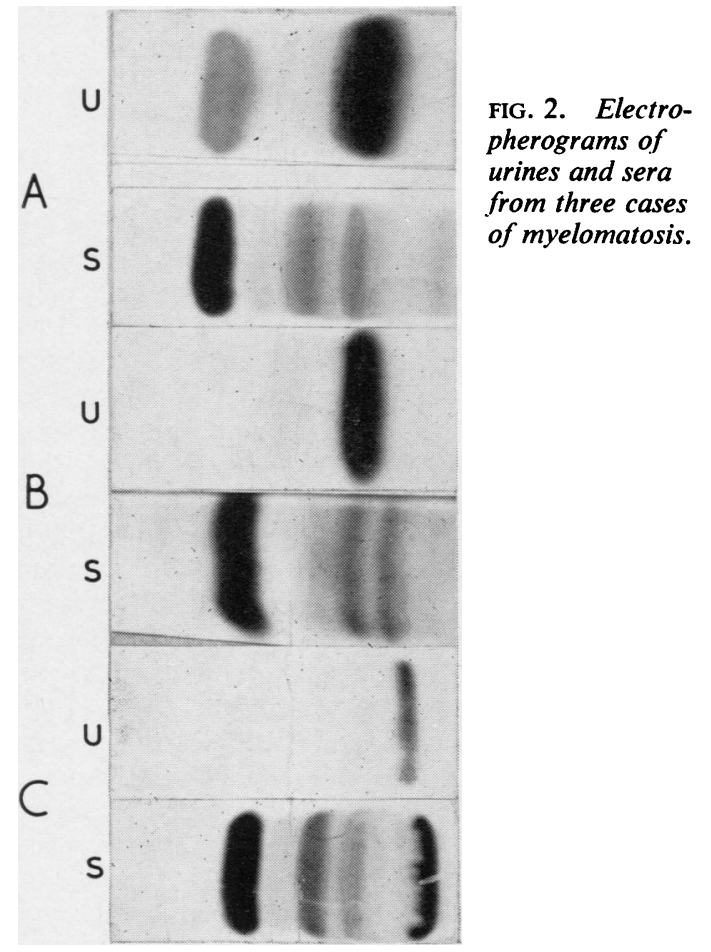

URINE ELECTROPHORESIS This was performed on 16 cases and in 13 of these the electropherogram of the concentrated urine was diagnostically important, especially $(a)$ in those cases where the 
serum electrophoresis was normal or nearly so; (b) in those with hypogammaglobulinaemia; and (c) in those patients whose diagnosis was missed by the clinicians. The urine electrophoretic pattern of the six cases which had a normal serum electrophoretic pattern showed that all the myeloma protein seemed to be excreted in the urine, sometimes accompanied by a small amount of both albumin and other globulins. Figure 2 shows typical electropherograms of both urine (U) and serum (S) from three patients with multiple myeloma. The serum electropherograms of both A and B show only minor non-specific changes, slight hypogammaglobulinaemia, and no detectable myeloma proteins, whereas the urine electropherograms in these cases show that all the abnormal protein is found in the urine. Although the Bence-Jones protein in $\mathrm{A}$ is accompanied by some albuminuria, the diagnosis is clear, since the dominant globulin band is obviously a Bence-Jones protein. Similarly in the urine electropherograms shown in Fig. 2, B and $\mathrm{C}$ show a single dominant band in the beta globulin region which is clearly a Bence-Jones protein. In Fig. 2C the Bence-Jones protein can be seen migrating in the same slow gamma globulin region as the serum myeloma protein.

\section{DISCUSSION}

Although specific comparative data are few, the finding of 39 cases of myelomatosis in Negroes in Jamaica within two years seems high. This figure is of the order of 20 cases per annum, and as it has since been estimated that our routine laboratory serves a population of not more than 400,000 people, this is equivalent to 50 cases per million per annum. The figure of 400,000 is an overestimation, since there are more than two other routine laboratories of equivalent size serving the same population. Furthermore there must be several cases of myeloma that go undiagnosed each year, due to the shortage of medical facilities in the Island. Clearly, then, the incidence of myeloma appears to be higher than the figure indicated here. MacMahon and Clark (1956), on the basis of a survey of 279 cases of myeloma in 34 Brooklyn hospitals in New York in the period 1943-53, reported the incidence of multiple myeloma in Negroes as 23.5 per million per annum which is more than twice the rate in whites in the same area, and the excess risk experienced by the nonwhite compared with the white population is probably closer to $100 \%$ than $20 \%$. Comparative statistics on the incidence of multiple myeloma in other countries are rare. However, Heinivaara and Eisalo (1960) saw 34 cases of myeloma from 1954 to 1959 at the Second Department of Medicine,
University of Helsinki. Ramot and Salomi (1964) reported that the frequency per 100,000 of myelor a for the years 1956-60 was found to be 4.69 for the European-American born Jews and 3.65 for the Asian-African born Jews. Waldenström (19 found 61 cases of multiple myeloma at Malm, Sweden, from a population of 200,000 during the 10 years between 1950 and 1959. This is equivale to about 30 cases per million per annum, whichgis significantly lower than the annual figure of the present myeloma series in Negroes in Jamaica and is of the same order as the figure of 26 cases pe्टr million per annum for England (Martin, 196\$. The significance of the high incidence of $m \&$ lomatosis in Negroes is not known, although it is tempting to suggest that some genetic factor may be involved.

In the present series $62 \%$ of the total cases were males. This is in agreement with the findings off other workers (Snapper, Turner, and Moscovitz, 1953; Martin, 1961). All that can be said concernirg the mean age incidence of 52 years for the present series is that it appears to be similar to that reporgd for Caucasians by previous workers.

A significant proportion of the cases, $25 \%$, in the present myeloma series, had a low total protein aqd globulin level. On electrophoresis it was found th as many as $60 \%(15 \%$ of the total number of cas of these gave a normal pattern or a pattern with ofy minor non-specific serum electrophoretic changes. On account of the normal serum electrophorefic pattern in these cases the laboratory diagnosis of multiple myeloma would most certainly have been missed if the urines had not been electrophoresed simultaneously.

In the present series the occurrence of the myeloge protein in the $\beta$-globulin region together wh hypogammaglobulinaemia was more common thian in the $\gamma$-globulin region, $40 \%$ of the former to $30 \%$ of the latter. In the literature the highest percentage of myelomas is usually found with slow gamma globulin mobility but the significance is not know. Alpha myelomas are extremely rare, and the pricsence of four in this series is indeed interesting. Infall four cases there was a single sharp peak in the serum $\alpha_{2}$ region. Two of these patients excreted BenceJones protein and in one of these the Bence-Joges protein had the same mobility as the corresponding serum myeloma protein.

However, Waldenström (1952), Osserman (1959), and others advise that myelomas should only be classified as $\alpha_{2}$ with great caution, since it is yell known that generalized carcinomas and infections which are so common in multiple myeloma nay give rise to a marked increase of alpha globulins?

Whenever a low globulin level with a normal 
serum electrophoretic pattern was encountered in a suspected case of multiple myeloma, attempts were specially made to obtain a specimen of urine from such patients for electrophoretic examination. Invariably, simultaneous electrophoresis of such sera and urines of these patients proved to be diagnostic even when the heat test for Bence-Jones protein was negative. During this study it was found that simultaneous electrophoresis of the serum and urine was the first means of detecting multiple myeloma in no less than $20 \%$ of the cases. These were subsequently confirmed either by bone marrow biopsy or by $x$-ray studies or both. Recently Clough and Reah (1964) observed that over a three-year period 15 cases of multiple myeloma had been detected in the Biochemistry Department entirely by careful examination of urinary and serum proteins.

More conclusive diagnostic results were obtained when urines from suspected patients were rapidly concentrated and electrophoresed on cellulose acetate than from attempting to do the heat test for Bence-Jones protein. Osserman and Lawlor (1955) reported three cases which gave negative results by the heat test but a positive reaction for Bence-Jones protein was found on urine electrophoresis. Owen and Rider (1957) showed that the two main criteria on which the usual heat test for Bence-Jones protein depend are unreliable, and Burtin (1964) stated that urinary electrophoresis provides a more reliable means of evaluation, when it discloses the existence of a unique urinary protein with $\beta$ - $\gamma$ or intermediate mobility.

The results presented here confirm the findings of previous publications (Owen and Rider, 1957; Osserman, 1959; Waldenström, 1962) that about $85 \%$ of myeloma sera show the typical 'church spire' pattern on electrophoresis; the other $15 \%$ may show only hypogammaglobulinaemia or a normal pattern or an electrophoretic pattern with minor non-specific changes. However, in this $15 \%$ of patients when the urine is electrophoresed simultaneously with the serum diagnostic results have been obtained. It is suggested, therefore, that both serum and urinary electrophoresis should be performed in all cases of suspected myelomatosis, particularly those with abnormal or low total serum protein. No false positive results were obtained by this procedure, and in fact it should be pointed out that one was able to rule out a diagnosis of multiple myeloma in several patients when their combined serum and urine showed no characteristic pattern. It was also found that this procedure was especially useful in those cases of multiple myeloma in which inconclusive findings were obtained in either the radiological or bone marrow biopsy investigations or both.

I wish to thank Professor Bras, Head of the Department of Pathology, University of the West Indies, for his interest in this work; Mrs. Jackie Chang, and other technicians of the Sub-department of Chemical Pathology for technical assistance, Dr. L. M. Burke, St. James Hospital, Montego Bay, for his assistance in sending me information on some of the patients, and Mr. D. D. Simmonds, University of Ibadan, for his assistance with the diagrams.

\section{REFERENCES}

Burtin, P. (1964). Immuno Electrophoretic Analysis, p. 160, edited by P. Grabar and P. Burtin. Elsevier, Amsterdam.

Clough, G., and Reah, T. G. (1964). Lancet, 1, 1248.

Gornall, A. G., Bardawill, C. J., and David, M. M. (1949). J. biol. Chem., 177, 751.

Heinivaara, O., and Eisalo, A. (1960). Acta med. scand., 168, 211.

Longsworth, L. G., Shedlowsky, T., and MacInnes, D. A. (1939). J. exp. Med., 70, 399.

McFarlane, H. (1963). W. Indian med. J., 12, 171.

(1964). Clin. chim. Acta, 9, 376.

MacMahon, B., and Clark, D. W. (1956). J. chron. Dis., 4, 508

Martin, N. H. (1961). Lancet, 1, 237.

Osserman, E. F. (1959). New Engl. J. Med., 261, 952.

- , and Lawlor, D. P. (1955). Amer. J. Med., 18, 462.

Owen, J. A., and Rider, W. B. (1957). J. clin. Path., 10, 373.

Ramot, B., and Salomi, M. (1961). Lancet, 2, 725.

Snapper, I., Turner, L. B., and Moscovitz, H. L. (1953). Multiple Myeloma. Grune and Stratton, New York.

Varley, H. (1962). Practical Clinical Biochemistry, 3rd ed. Heinemann, London.

Waldenström, J. (1952). Advanc. intern. Med., 5, 398.

_ (1962). Progr. Hemat., 3, 266. 